\title{
Fire Danger on Jambi Peatland Indonesia based on Weather Research and Forecasting Model
}

\author{
Lisnawati ${ }^{1,2}$, Muh Taufik1, Bambang Dwi Dasanto', Ardhasena Sopaheluwakan² \\ ${ }^{1}$ Department of Geophysics and Meteorology, Faculty of Mathematics and Natural Sciences, IPB University, Dramaga Campus, \\ Bogor, Indonesia 16680 \\ ${ }^{2}$ Meteorological, Climatological, and Geophysical Agency, Kemayoran, Jakarta Pusat, DKI Jakarta, Indonesia 10610
}

\section{ARTICLE INFO}

Received

7 October 2021

Revised

12 November 2021

\section{Accepted for Publication}

26 November 2021

\section{Published}

21 January 2022

doi: 10.29244/j.agromet.36.1.1-10

\author{
Correspondence: \\ Muh Taufik \\ Department of Geophysics and \\ Meteorology, Faculty of Mathematics \\ and Natural Sciences, IPB University, \\ Dramaga Campus, Bogor, Indonesia \\ 16680. \\ Email: mtaufik@apps.ipb.ac.id
}

This is an open-access article distributed under the CC BY License. (c) 2022 The Authors. Agromet.

\begin{abstract}
A B S T R A C T
Monitoring drought related to peat fire danger is becoming essentials due to the adverse impacts of peat fires. However, the current monitoring is mostly based on station data and has not yet covered all parts of peatlands. This research was carried out to initiate a spatial monitoring for peat fire, particularly in Jambi province. Our approach was simple by integrating Weather Research Forecasting (WRF) output with a drought-fire model. This research aims to: (i) calibrate rainfall, air temperature and soil moisture data from WRF output; and (ii) analyze temporal drought related to fire danger. A drought-fire model known as Peat Fire Vulnerability Index was applied with daily inputs of WRF output at $5 \mathrm{~km}$ resolution, which were comprised of rainfall, air temperature, and soil moisture. The results showed that calibration reduced rainfall magnitude, and slightly increased the maximum air temperature and soil moisture. The calibration performance was good as shown by a very low percent bias (less than $\pm 5 \%$ ), and lower error (RMSE $=16.5$; $M A E=9.5)$. Our analysis showed that drought triggered by El Niño in 2015 had escalated extreme fire danger class by $38 \%$ compared to normal year (2018). This has been confirmed by a low variation of proportion of extreme class during July-August 2015 . The results suggested that integrating spatial global climate data will benefit to the improved drought-fire model by providing spatial data. The results are expected to be a reference on drought and peat fires mitigation action.
\end{abstract}

\section{KEYWORDS}

bias correction, El Niño, fire danger class, peat fire vulnerability index, statistical indicators

\section{INTRODUCTION}

Peatland fires have become one of catastrophic disasters in Indonesia, particularly in dry season. The adverse impacts of peat fires became worse when it coincided with El Nino Southern Oscillation (Nurdiati et al., 2021; Pan et al., 2018; Taufik et al., 2017). In 2015, for example, fires coincided with strong El-Nino have devastated 2.6 million ha peatland (World Bank, 2016). Peatland fires produced thick haze (Hayasaka and Sepriando, 2018; Hu et al., 2018; Yulianti et al., 2020), which caused health hazard (Sharma and Balasubramanian, 2018; Uda et al., 2019; Zaini et al.,
2020) and disrupted both land and air transportation (Ismanto et al., 2019a, 2019b), as well as economic loss for about USD 16 million (World Bank, 2016). To overcome the future risk of recurrent peat fires, Indonesian government established Peat Restoration Agency (now is BRGM) with a mandate to restore the degraded peatlands in Indonesia, including Jambi.

Jambi is one of the high priority provinces, which received the restoration program from BRGM. Its peatland covers about 0.6 million ha ( $9 \%$ of total peat land in Sumatera). Based on a critical level derived from land use, there was about $18 \%$ of peatland in Jambi 
categorized into a very critical status (Nurjanah et al., 2013). Currently, the dryness level of peatland in Jambi is monitored based on ground water level measurement at several stations. However, the monitoring has not yet covered all the region of Jambi peatland. Thus, spatial monitoring, particularly for fire risk on peatland, is required.

Peat fire is associated with drought events. The spatial monitoring for peat fire danger has been proposed earlier by integrating spatial climate data combined with drought fire model (Bourgeau-Chavez et al., 2020; Jolly et al., 2019). Spatial climate data can be derived from climate model, such as through Weather and Research Forecasting (WRF) model (Nuryanto et al., 2020; Sanusi et al., 2021). WRF model is widely used to generate climate data, including rainfall and air temperature (e.g. Chawla et al., 2018; Patel et al., 2020; Sati and Mohan, 2018; Teklay et al., 2019; Yáñez-Morroni et al., 2018), since it can produce data in various spatial resolution (Tao et al., 2020), and it is able to forecast data up to 16 days (Skamarock et al., 2021). Furthermore, the WRF model can estimate soil moisture as proxy of groundwater table, which is an essential variable for calculating drought on peatland.

There are some models which can be used to monitor drought related to forest fire danger, including Peat Fire Vulnerability Index (PFVI). PFVI is the advanced model of drought-fire index which was specifically designed for tropical peatland (Taufik et al., 2022). It was based on Keetch Byram Drought Index. This model has been tested to assess fire events in Jambi dan West Kalimantan, which gave a good result. Yet, there is no previous study which integrate this model with spatial climate data in tropical peatland Indonesia.

This research will assess drought-fire events in Jambi province from 2015 to 2018 by employing the output of WRF model to PFVI. This research specifically aims to: (i) calibrate rainfall, air temperature and soil moisture data from WRF output; and (ii) analyze both spatial and temporal drought related to fire risk. The results are expected to be a reference on drought and peat fires mitigation.

\section{RESEARCH METHODS}

\section{Data Source}

To running the WRF model, we used Global Forecasting System (GFS) dataset produced by National Centers for Environmental Prediction (NCEP) as the data input. The GFS data has a spatial resolution of $0.5^{\circ}$ and temporal scale of 3 hours. In this research, WRF model was set to produce climate data in spatial resolution $\sim 5 \mathrm{~km}$. The modeling was daily run for 2015 to 2018 in which the analysis mainly focused on fire season. Based on the GFS data, the analysis was divided into four group periods of data (Table 1). Three variables used for drought-fire model, namely rainfall, air temperature, and soil moisture at level 1 was obtained from modeling. The WRF output data were then calibrated by the observed meteorological data obtained from Ogimet (https://www.ogimet.com/). The Ogimet's climate data was selected only from several stations in surrounding of Jambi. Meanwhile, the observed soil moisture data was obtained from field measurement used by SiGambut ${ }^{1}$ calibration.

Table 1. The range period of WRF output data for each group analysis.

\begin{tabular}{cl}
\hline Group & \multicolumn{1}{c}{ Range data } \\
\hline Period1 & Jan-Aug 2015 \\
\hline Period2 & Oct 2015-Apr 2016 \\
\hline Period3 & Jul 2016-Mar 2018 \\
\hline Period4 & May-Dec 2018 \\
\hline
\end{tabular}

\section{WRF Model Setup}

Technically, there are two applications needed to be installed to run WRF model, i.e. WRF processing system (WPS) and WRF program. WPS is a program that determines model domains and interpolates terrestrial data. This research used two nested domains set in different spatial resolution, which were domain1 (d01) for $15 \mathrm{~km}$, and domain2 (d02) for $5 \mathrm{~km}$ (Figure 1).

The set up for WRF model, which will be run in WPS was written in file "namelist.wps". It contained information about geographical positions of the area of interest, as well as resolution and extent data output. Furthermore, there are five libraries, which are needed to be prepared in the same directory with WRF model, namely NetCDF, MPICH, zlib, libpng, and Jasper. Those are used to read and process Global Forecasting System (GFS) as the input of WRF model based on specific location and time.

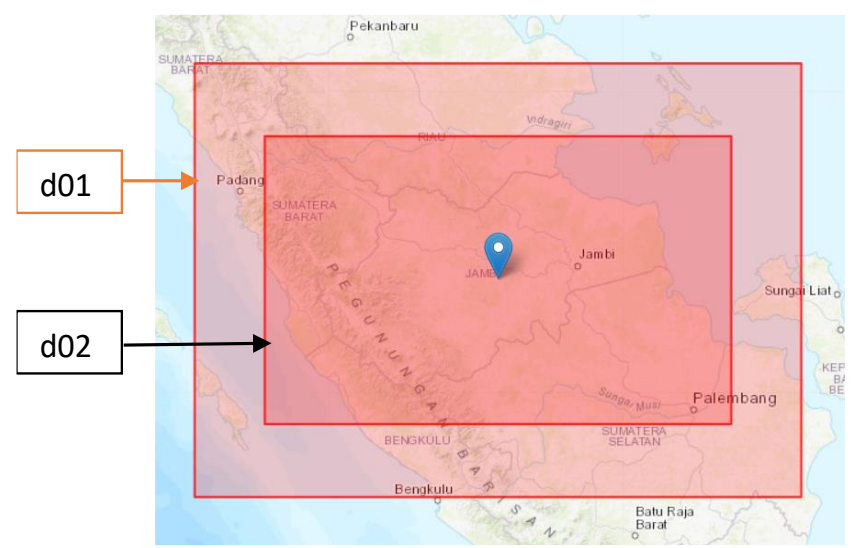

Figure 1. The domains zona used in this research.

\footnotetext{
${ }^{1}$ https://sigambut.hidro-ipb.com/
} 
After that, the GFS data was processed using "ungrib.exe" program and interpolated horizontally using "metgrid.exe" program. The output of WPS model, in the form of a met em* file, was then analyzed by WRF model employing "real.exe" and "wrf.exe" programs. The "real.exe" program indicates that the model is running the system from real-world data in the atmosphere and on the earth's surface with physical weather parameters, while the "wrf.exe" program runs the parameter scheme ("namelist.input") arranged according to the needs of the weather prediction.

In this research, we modified five weather physical parameters used in WRF model following Sanusi et al. (2021), namely cloud microphysical parameters, cumulus clouds $(\mathrm{Cu})$, planetary boundary layer (PBL), long-wave radiation and short-wave radiation. These five physical parameters have a strong influence on WRF model's result, particularly for rainfall data. The cloud microphysical parameters, i.e. $\mathrm{Cu}$ and $\mathrm{PBL}$, were crucial for simulating precipitation and were likely to influence both the spatial and temporal variability of the rainfall data (Nuijens and Siebesma, 2019; Zheng et al., 2017). Here, we followed the parameterization scheme resulted by Sanusi et al. (2021), which are listed in Table 2. The WRF model's output named as wrfout_d02 was then converted to NetCDF data. The climate data was then processed using $R$ language ( $R$ Core Team, 2016) to obtain hydrometeorological data needed.

\section{Calibration of WRF Output data}

Climate data derived from WRF model needs to be calibrated to represent local climate conditions. The calibration process was divided into two types, namely spatial-based calibration, and point-based calibration. Spatial calibration was applied to rainfall and air temperature, while the point-based was for soil moisture variable. For spatial, climate data from Ogimet stations were interpolated using inverse distance weighting (IDW) methods to derive spatial observed data. The IDW method had been proven better to correct rainfall data from WRF (Sanusi et al., 2021). The

Table 2. The selected scheme for WRF parameters used in this research.

\begin{tabular}{ll}
\hline \multicolumn{1}{c}{ WRF Parameters } & \multicolumn{1}{c}{ Selected Scheme } \\
\hline cloud microphysics & Eta Scheme \\
\hline cumulus clouds (Cu) & $\begin{array}{l}\text { Grell-Devenyi (GD) } \\
\text { Ensamble Scheme }\end{array}$ \\
\hline $\begin{array}{l}\text { planetary boundary } \\
\text { layer (PBL) }\end{array}$ & $\begin{array}{l}\text { Mellor-Yamada-Janjic (MYJ) } \\
\text { Scheme }\end{array}$ \\
\hline long-wave radiation & Rapid Radiative Transfer \\
& Model (RRTM) Scheme \\
\hline short-wave radiation & New Goddard Scheme \\
\hline
\end{tabular}

WRF climate data (rainfall and air temperature) were then bias corrected using gamma quantile method (Piani et al., 2010). For point-based calibration, the soil moisture data were corrected using the pair of data between WRF output and field data, which were taken from previous work (SiGambut). The bias correction for soil moisture variable was based on scaling method. The correction process was done using package 'hyfo' $(X u, 2015)$ from $R$ language program ( $R$ Core Team, 2016).

To evaluate the WRF model performance in predicting climate variables, we used five indicators of statistical goodness of fit, as follow:

1. Root Mean Square Error (RMSE)

RMSE is a statistical indicator used to estimate the error value of a data model (Harwell, 2019). The model's quality and accuracy will improve as the error value decreases, as indicated by a lower RMSE value. RMSE calculation based on Equation 1.

$$
R M S E=\sqrt{\sum_{i=1}^{n}\left(x_{i}-y_{i}\right)^{2}}
$$

where $y_{i}$ is the WRF model output data for day-i, $x_{i}$ is the observation measurement data for day- $i$, and $n$ is the total length of the data.

2. Mean Absolute Error (MAE)

MAE indicates accuracy model data compared to observed data. MAE value, which is closer to 0 , shows the higher model's accuracy. Equation 2 is the mathematical term to calculate MAE.

$M A E=\frac{\sum_{i=1}^{n}\left|y_{i}-x_{i}\right|}{n}$

\section{Nash-Sutcliffe Efficiency (NSE)}

NSE calculates the relative value and residual variance of observational data in comparison to the variance (Tegegne et al., 2017). The NSE value ranges between $\infty$ and 1 . The closer to one means the smaller the residual value, which indicates that the model output data is better and more acceptable. Equation 3 is used to calculate NSE value.

$N S E=1-\left[\frac{\sum_{i=1}^{n}\left(x_{i}-y_{i}\right)^{2}}{\sum\left(x_{i}-x_{\text {mean }}\right)^{2}}\right]$

\section{Percent Bias (PBIAS)}

PBIAS is used to determine the average trend of greater or lesser trends in model data compared to observed data. The lower bias value indicates by PBIAS value close to zero. Positive PBIAS value means model data underestimate, whereas negative PBIAS value means overestimation. Equation 4 shows the formula for calculating PBIAS.

$$
\text { PBIAS }=\left[\frac{\sum_{i=1}^{n}\left(x_{i}-y_{i}\right) \times 100}{\sum_{i=1}^{n} x_{i}}\right]
$$




\section{Pearson Correlation ( $r$ )}

The correlation is derived from the linear relationship between model and observed data. Positive correlation value means a one-way relationship between the model and the observation data, while the negative value means the inverse relationship. The range value for Pearson's correlation is between -1 and 1 . The closer value toward 1 or -1 indicates the stronger relationship between model and observed data. Meanwhile, low correlation value, which is close to 0 , shows the weaker the relationship. Equation 5 depicts the Pearson Correlation calculation.

$$
r=\sqrt{1-\left(\frac{\sum_{i=1}^{n}\left(x_{i}-y_{i}\right)^{2}}{\sum_{i=1}^{n}\left(x_{i}-\underline{y_{i}}\right)^{2}}\right)}
$$

\section{Drought-Fire Model for peatland}

To quantify drought potency related to fire danger in Jambi, we integrated PFVI model with corrected WRF climate data. The drought model is formed by three predictors, namely drought factor (DF), rainfall factor (RF), and water table factor (WTF), and they were calculated on daily basis (Equation 6). The DF is the only factor which increase the drought index, while RF and WTF have a role as deduction of index value. DF were calculated based on maximum air temperature $(T)$ and annual rainfall $(R o)$ as shown in Equation 7. In this research, annual rainfall in Jambi is about 2,500 $\mathrm{mm}$.

$$
\begin{aligned}
& P F V I^{t}=P F V I^{t-1}+D F^{t}-R F^{t}-W T F^{t} \\
& D F^{t}=\frac{\left(300-m K B D I^{t-1}\right) \times\left(0.4982 e^{(0.0905 \times T+1.6096)}-4.268\right) \times 10^{-3}}{1+10.88 e^{(-0.001736 \times R o)}}
\end{aligned}
$$

where $t$ is at daily resolution, $T$ maximum air temperature $\left({ }^{\circ} \mathrm{C}\right)$, and $R o$ annual rainfall $(\mathrm{mm})$.

The RF parameter was calculated as the net rainfall, which accumulated in a day. There are three conditions used to calculate the net rainfall (Equation 8). The $5.1 \mathrm{~mm}$ reduction in rainfall refers to rainfall interception in vegetation cover. The WTF parameter was originally calculated based on the ground water level data. Yet, in this research, we employed the spatial soil moisture data from WRF to calculate the WTF parameter (Equation 9). Soil moisture data were then rescaled to represent the state of wetness condition based on fitting process done by Taufik et al. (2022).

$R F^{t}=\left\{\begin{array}{c}\left(R^{t}-5.1\right) ; R^{t} \geq 5.1 \mathrm{~mm} / \text { day } \\ R^{t} ; R^{t-1} \geq 5.1 \mathrm{~mm} / \text { day and } R^{t} \geq 5.1 \mathrm{~mm} / \text { day } \\ 0 ; R^{t}<5.1 \mathrm{~mm} / \text { day }\end{array}\right.$

$W T F^{t}=5.67-0.116 \times s m^{*}$

where $R$ denotes daily rainfall $(\mathrm{mm})$, and $s m^{*}$ rescaled daily soil moisture.
In this research, PFVI index ranges from 0 to 300 followed the research finding by Taufik et al. (2022). Zero means moisture at saturated level, while 300 represents the driest moisture at wilting point. For initial value of index, we set four different number for each period, which are 100, 250, 200, and 200 for period 1 until period4, respectively. The initial numbers were based on the climate condition of each first month. For spatial and temporal analysis, the drought index was then classified into four categories, namely low, moderate, high, and extreme (Table 3). All calculation and analysis were done by using $\mathrm{R}$ language program.

Table 3. The Peat Fire Vulnerability Index (PFVI) classification.

\begin{tabular}{cl}
\hline PFVI value & Category \\
\hline $0-75$ & Low \\
\hline $76-150$ & Moderate \\
\hline $151-225$ & High \\
\hline $226-300$ & Extreme \\
\hline
\end{tabular}

\section{RESULTS AND DISCUSSIONS}

\section{Corrected WRF Output}

The WRF rainfall data were calibrated using several observed rainfall data, which was interpolated into spatial rainfall using inverse distance weighting (IDW) method. In general, the correction results of WRF data for rainfall variable showed that the original WRF output were overestimate. It was confirmed by the statistical distribution data shown in boxplot (Figure 2). The uncorrected rainfall data had median value about $18 \mathrm{~mm} /$ day, while the median for the corrected one was about $5 \mathrm{~mm} /$ day. The range value (first quartile to the third) was also decreased by about a half in comparison between before and after correction.

Based on the indicator goodness of fits value between WRF output and observed data, there were significant improvement of the WRF data after correction process (Table 4). For rainfall, the average RMSE and MAE scores decreased by about a half. The decrease was from 28.1 to 16.5 for RMSE, and 16.5 to 9.5 for MAE. All NSE values had the negative results but the numbers for after correction substantially decreased. The bias correction result was mostly shown on the PBIAS value, which plummeted from 123.8 to 1.6 in negative average value. Specifically, the corrected data mostly had a positive PBIAS, which means the corrected WRF data was lower than the observed one (underestimate). Only in period3, the PBIAS was still in negative value. The correlation had the least changes between before and after correction among the other indicators. 


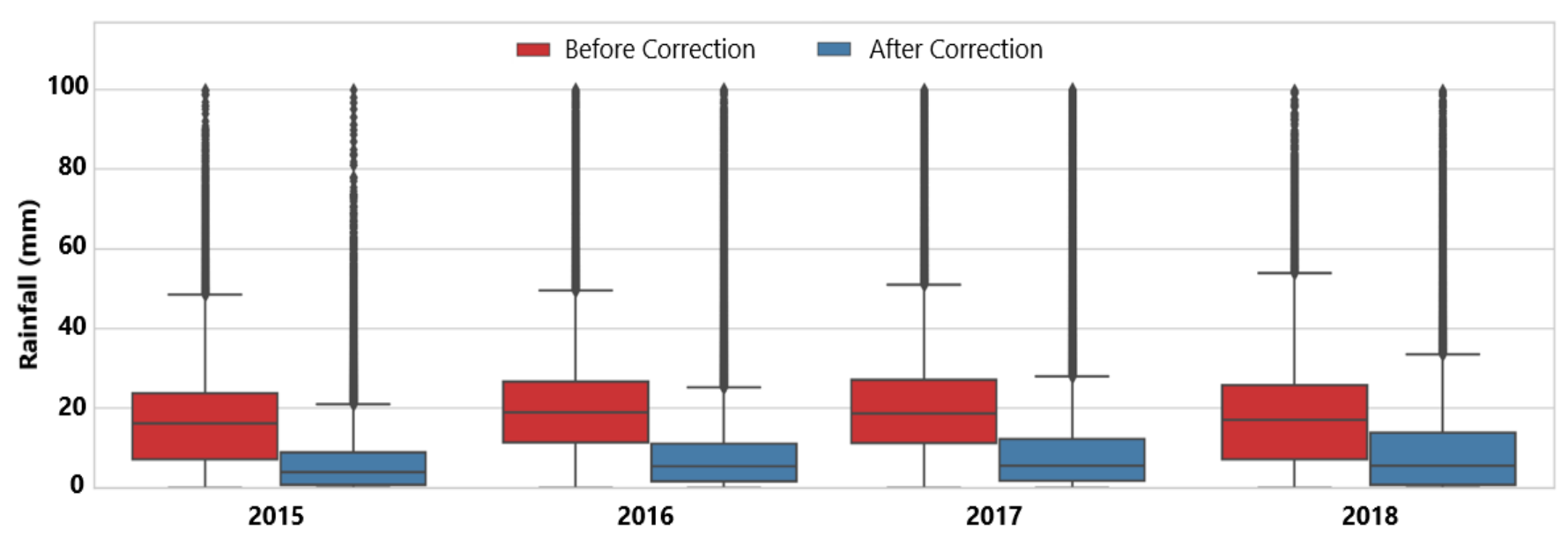

Figure 2. Comparison the boxplot of WRF rainfall data before (red) and after (blue) correction process for each year analysis during 2015-2018. The y-axis is limited to $100 \mathrm{~mm}$ as not many rainfalls exceed the value.

For air temperature, the values goodness of fits for corrected WRF output had a small difference than the uncorrected one. The difference was due to the low variability of air temperature in tropical region. It also indicated that the original WRF data could be used in calculation. Spatially, after calibration, the corrected temperature was higher than the uncorrected WRF output. An increase pattern was observed in most part of Jambi peatland at least $0.5^{\circ} \mathrm{C}$ (Figure 3a).
Soil moisture data was not corrected by spatial observed data, yet it was based on the factor bias correction, which was resulted from WRF and observed data in 2019. Overall, the bias correction process resulted the higher value of soil moisture (Figure $3 b$ ). In all periods of data correction, the corrected data ranged between 0.5 and 0.7 . Those values were about 0.2 higher than the uncorrected soil moisture, which varied from 0.2 to 0.4 .

Table 4. Indicators of statistical goodness of fit for calibration WRF output (rainfall and maximum air temperature) for four different periods of analysis in Jambi peatland.

\begin{tabular}{|c|c|c|c|c|c|c|}
\hline \multirow{2}{*}{ Period } & \multirow{2}{*}{ Range of Data } & \multirow{2}{*}{$\begin{array}{l}\text { Statistical } \\
\text { Indicator }\end{array}$} & \multicolumn{2}{|c|}{ Rainfall } & \multicolumn{2}{|c|}{ Maximum Air Temperature } \\
\hline & & & Uncorrected & Corrected & Uncorrected & Corrected \\
\hline \multirow{5}{*}{ Period1 } & \multirow{5}{*}{ Jan-Aug 2015} & RMSE & 36.44 & 12.55 & 1.33 & 1.08 \\
\hline & & MAE & 15.65 & 7.11 & 1.08 & 0.83 \\
\hline & & NSE & -10.96 & -0.31 & -0.64 & -0.03 \\
\hline & & PBIAS & -132.19 & 3.78 & 2.08 & 0.00 \\
\hline & & $r$ & 0.02 & 0.10 & 0.43 & 0.42 \\
\hline \multirow{5}{*}{ Period2 } & \multirow{5}{*}{ Oct 2015-Apr 2016} & RMSE & 20.94 & 15.28 & 1.29 & 1.20 \\
\hline & & MAE & 16.40 & 9.43 & 1.07 & 0.97 \\
\hline & & NSE & -1.81 & -0.44 & -0.65 & -0.36 \\
\hline & & PBIAS & -132.72 & 5.41 & 0.54 & 0.00 \\
\hline & & r & 0.10 & 0.13 & 0.37 & 0.36 \\
\hline \multirow{5}{*}{ Period3 } & \multirow{5}{*}{ Jul 2016-Mar 2018} & RMSE & 34.40 & 18.55 & 1.30 & 1.20 \\
\hline & & MAE & 18.84 & 10.60 & 1.05 & 0.96 \\
\hline & & NSE & -5.33 & -0.72 & -0.77 & -0.47 \\
\hline & & PBIAS & -152.19 & -19.79 & 0.73 & -0.01 \\
\hline & & r & 0.01 & 0.03 & 0.31 & 0.31 \\
\hline \multirow{5}{*}{ Period4 } & \multirow{5}{*}{ May-Dec 2018} & RMSE & 20.51 & 19.65 & 1.14 & 0.99 \\
\hline & & MAE & 15.20 & 11.08 & 0.92 & 0.80 \\
\hline & & NSE & -0.48 & -0.35 & -0.76 & -0.29 \\
\hline & & PBIAS & -78.15 & 3.97 & 1.41 & 0.00 \\
\hline & & r & 0.14 & 0.14 & 0.32 & 0.31 \\
\hline
\end{tabular}


(a) Max. Air Temperature

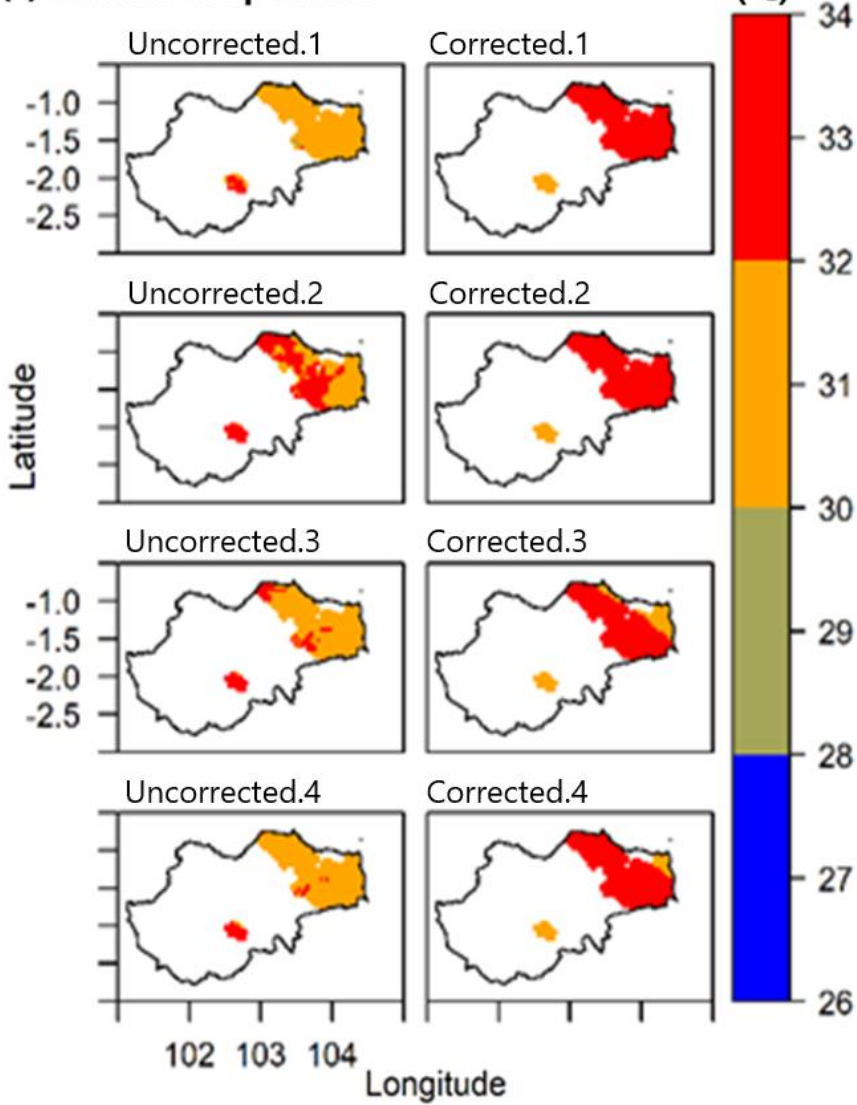

\section{(b) Soil Moisture}

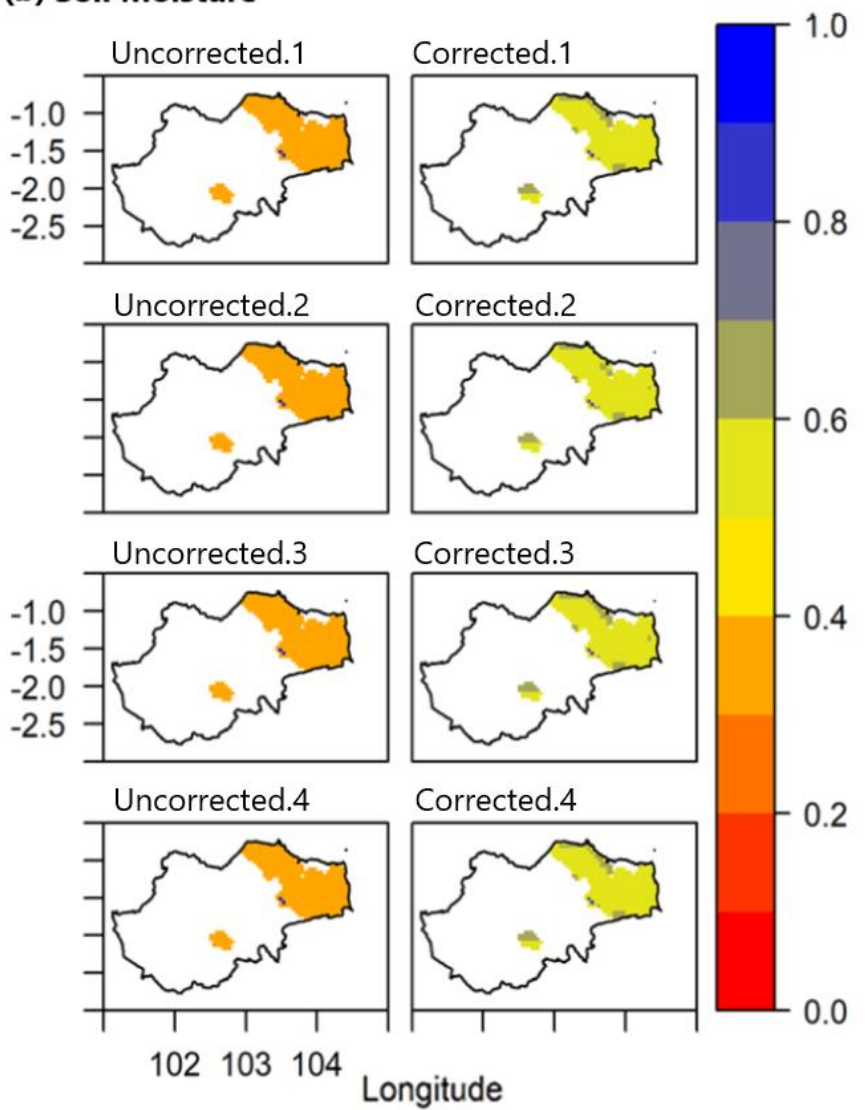

Figure 3. Comparison of average value between uncorrected and corrected WRF data for Jambi peatland. The number on each sub-title denotes the period of data.

\section{Drought-fire danger in Jambi Peatland}

Drought vulnerability in Jambi's peatland was quantified by integrating corrected climate data from WRF model with drought-fire model. Since the peatland is usually burned in dry season, the drought analysis only focused on July and August each year of 2015-2018. Based on the annual analysis of PFVI classification (Table 5), 2015 had the highest proportion of high and extreme classes, which was up to $80 \%$. In specific, the highest proportion of peatland area for only extreme class was occurred on 1 August 2015 covered more than 60\% (Figure 4a). In 2016, the percentage of high and extreme classes decreased to less than $50 \%$, and the highest one was the moderate class (48\%). The similar proportion class was also found in 2018. The different proportion was found in 2017, where the high class became the highest (accounted for about $38 \%$ ). Yet, the accumulation for high and extreme class was exceeded $60 \%$. In the daily proportion, the highest extreme class proportion in 2017 was happened on 5 August having up to 68\% (Figure 4c).

The proportion of drought class was analyzed on the daily timescale (Figure 4) to obtain general pattern of drought class each year. In general, the class proportion in 2015 has the least variability during dry season compared to others. In 2016 (Figure 4b), there were several days when all peatland area were included to moderate class (10-12 July). There was no area classified into extreme in July 2016. In August 2016, however, the extreme class emerged, and it rose to $42 \%$ in two weeks. The drought class proportion in 2017 had the highest variability (Figure 4c). From July to the early August, the extreme class gradually increased from about $10 \%$ to the highest point (68\%) on 5 August. The extreme was then dropped to the initial value in only about 12 days. For 2018 (Figure 4d), even though the overall proportion was similar with that of 2016 (refer to Table 4), it had a different pattern of daily class proportion change. Started from the end of July, the extreme class was only fluctuated between $10-30 \%$.

Table 5. Annual proportion of each Peat Fire Vulnerability Index (PFVI) classification in Jambi peatland from 2015 to 2018.

\begin{tabular}{lrrrr}
\hline \multirow{2}{*}{ PFVI } & \multicolumn{4}{c}{ Annual Proportion (\%) } \\
\cline { 2 - 5 } \multicolumn{1}{c}{ Class } & $\mathbf{2 0 1 5}$ & $\mathbf{2 0 1 6}$ & $\mathbf{2 0 1 7}$ & $\mathbf{2 0 1 8}$ \\
\hline Low & 3,68 & 3,15 & 8,34 & 5,72 \\
\hline Moderate & 16,03 & 48,79 & 24,91 & 44,13 \\
\hline High & 32,03 & 35,14 & 37,78 & 39,30 \\
\hline Extreme & 48,26 & 12,92 & 28,96 & 10,85 \\
\hline
\end{tabular}




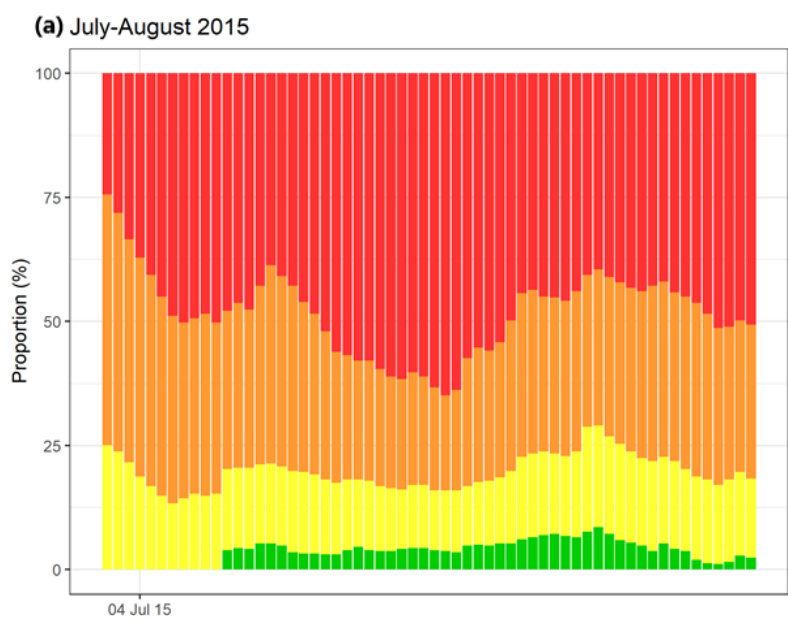

(b) July-August 2016
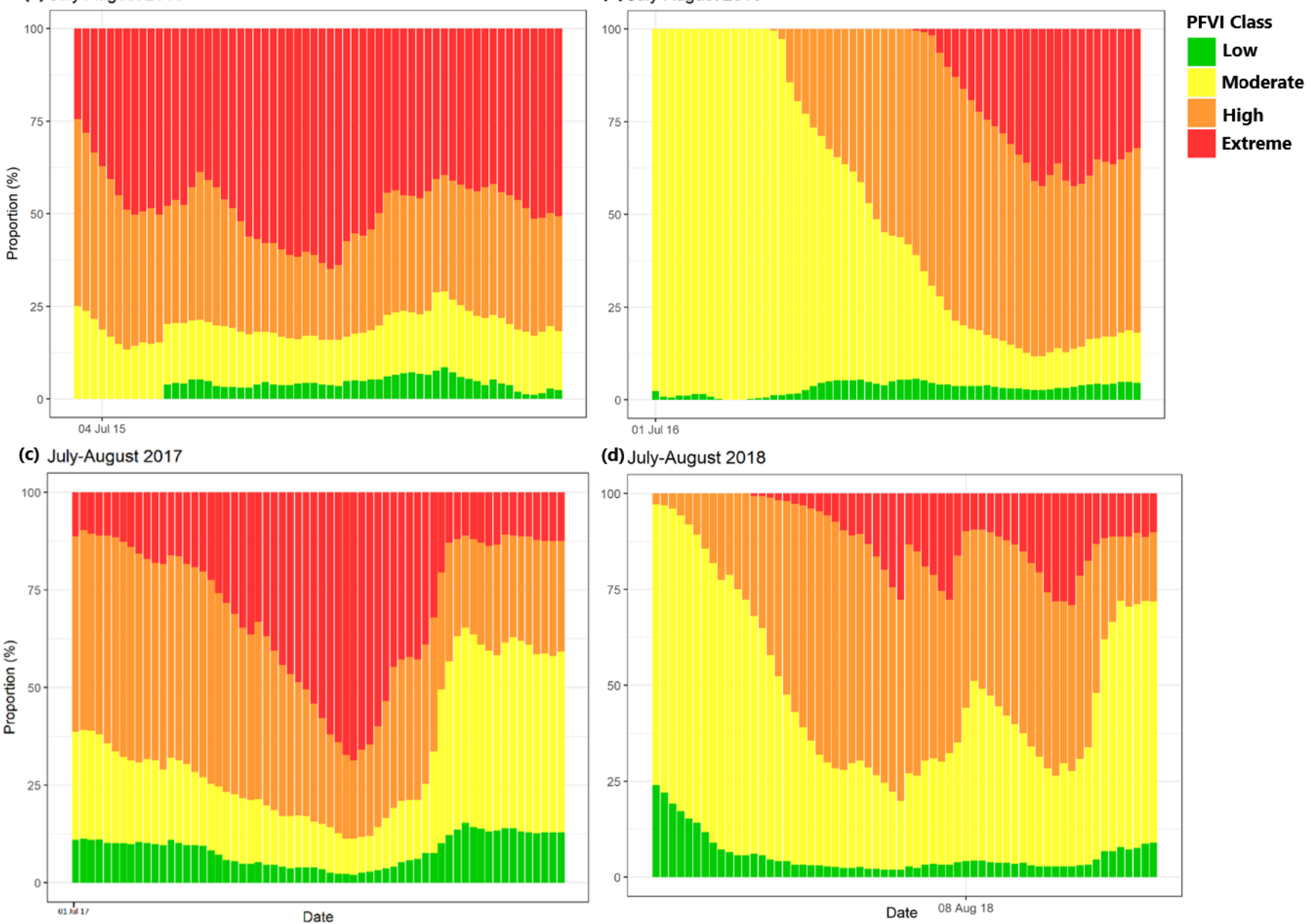

(d) July-August 2018

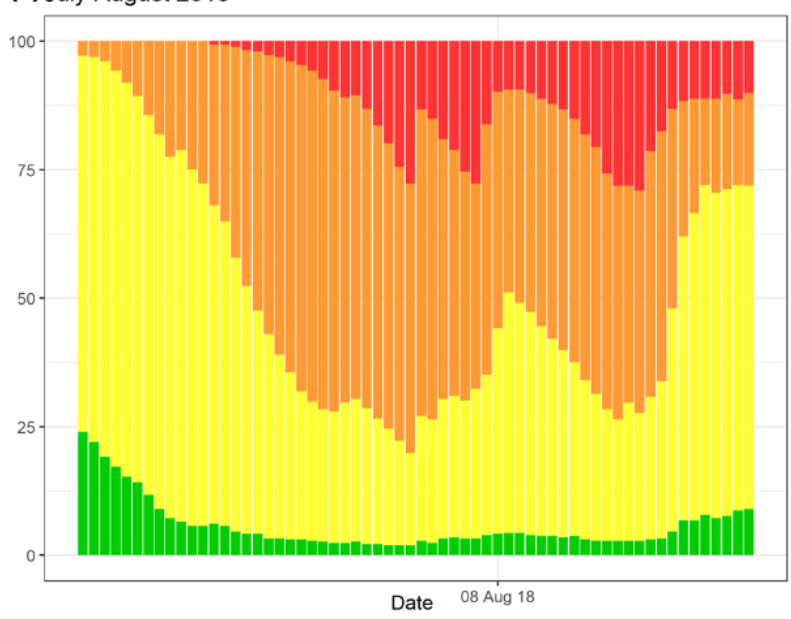

Figure 4. Dynamics of the daily proportion of fire danger class in Jambi peatland from 2015 to 2018.

Next, we analyzed the occurrence of extreme class in each month. This information was presented in occurrence dates and summarized in Table 6. Overall, the extreme class in 2015 had the highest frequency compared to the other years. The extreme class was almost recorded in every day. Other classes were barely found in 2015. The second most frequent of extreme classes was in 2017. It was started at the end of March and continued until the early October. The other two years, 2016 and 2018, had two periods of months contained extreme class, and 2018 was more frequent. The first period was in Feb-Mar, while the second was Jul-Oct. Year of 2016 became the least frequent since it only had 6 days of extreme class in the first period and 76 days in the second period.

Table 6. Dates of occurrence of the extreme class on Jambi peatland from 2015 to 2018.

\begin{tabular}{ccccc}
\hline Month & $\mathbf{2 0 1 5}$ & $\mathbf{2 0 1 6}$ & $\mathbf{2 0 1 7}$ & $\mathbf{2 0 1 8}$ \\
\hline Jan & $1-26,28-30$ & - & - & - \\
\hline Feb & $2-28$ & - & - & $11-28$ \\
\hline Mar & $1-31$ & $17-21,30$ & 31 & $1-3$ \\
\hline Apr & $1-30$ & - & $1-6$ & No Data \\
\hline May & $1-17,19-31$ & No Data & $28-31$ & - \\
\hline Jun & $1-30$ & No Data & $1-30$ & - \\
\hline Jul & $1-31$ & - & $1-31$ & $13-31$ \\
\hline Aug & $1-29$ & $3-31$ & $1-31$ & $1-31$ \\
\hline Sep & No Data & $1-30$ & $1-30$ & $1-30$ \\
\hline Oct & $1-31$ & $1-15,27-28$ & $1-6$ & $1-20$ \\
\hline Nov & $1-30$ & - & - & - \\
\hline Dec & $1-26,28-30$ & - & - & - \\
\hline
\end{tabular}




\section{Limitation of Model}

There are several limitations, which can be potential drawbacks to this study. First, the WRF data was calibrated based on the interpolated climate data, which may lead to another bias from the interpolation process itself. In addition, we only used the meteorological data from the nearby airport, which are closely located to study site. A similar approach was used to calibrate global climate data based on meteorological station (Harris et al., 2020; Yue et al., 2021).

Second, there were an uncertainty about the use of soil moisture data as the input of WTF parameter. In this research, the ground water was approached by the function of upper soil moisture data from WRF model rescaled to a certain range, which may not represent actual groundwater depth at $5 \mathrm{~km}$ resolution.

Third, we used four different initial index value for each period. According to the original model, the initial index value should be set as saturated peatland condition (Taufik et al., 2015). Based on the mentioned limitation of this study, further work is necessary on employing climate data covering peatland area for WRF calibration, addressing the WTF parameter input for spatial calculation, and determining the suitable index value for initial condition. This research has provided the scientific foundation for further research on the enhancement of monitoring drought-fire risk for tropical peatland.

\section{CONCLUSION}

Drought analysis for peatland can be done by integrating spatial climate data from climate model combined with drought fire model. The climate data, as the input of drought model, needs to be calibrated to represent local climate conditions. The results showed that WRF calibration process reduced rainfall magnitude, and slightly increased the maximum air temperature and soil moisture. The bias correction's performance was good as shown by statistical indicators used. Furthermore, Jambi peatland had the highest proportion of extreme class of fire danger in dry season 2015. The daily changes of extreme class' proportion during July-August in 2015 was weakly fluctuated. The peatland experienced extreme class almost every day throughout the year of 2015. This research had several limitations, such as using a limited observed data, having an uncertainty about the water table factor parameter, and assuming certain numbers as the initial index. These drawbacks could be more exploited as further research on spatial peat fire monitoring.

\section{ACKNOWLEDGEMENT}

The author thanks to our colleagues for their assistance during data processing especially Alfi Rizky
Sanusi, Marliana Tri Widyastuti, and Agung Baruna Setiawan Noor. Thanks to BMKG for the endless support. The authors also thank to editor and two anonymous reviewers for their valuable comments that greatly improved the manuscript.

\section{REFERENCES}

Bourgeau-Chavez, L.L., Grelik, S.L., Billmire, M., Jenkins, L.K., Kasischke, E.S., Turetsky, M.R., 2020. Assessing Boreal Peat Fire Severity and Vulnerability of Peatlands to Early Season Wildland Fire. Frontiers in Forests and Global Change 3, 1-13. https://doi.org/10.3389/ffgc.2020.00020

Chawla, I., Osuri, K.K., Mujumdar, P.P., Niyogi, D., 2018. Assessment of the Weather Research and Forecasting (WRF) model for simulation of extreme rainfall events in the upper Ganga Basin. Hydrology and Earth System Sciences 22, 10951117. https://doi.org/10.5194/hess-22-10952018

Harris, I., Osborn, T.J., Jones, P., Lister, D., 2020. Version 4 of the CRU TS monthly high-resolution gridded multivariate climate dataset. Scientific Data 7, 109. https://doi.org/10.1038/s41597-020-04533

Harwell, M., 2019. A Strategy for Using Bias and RMSE as Outcomes in Monte Carlo Studies in Statistics. Journal of Modern Applied Statistical Methods 17, eP2938. https://dx.doi.org/10.22237/jmasm/1551907966

Hayasaka, H., Sepriando, A., 2018. Severe Air Pollution Due to Peat Fires During 2015 Super El Niño in Central Kalimantan, Indonesia, in: Vadrevu, K.P., Ohara, T., Justice, C. (Eds.), Land-Atmospheric Research Applications in South and Southeast Asia. Springer International Publishing, Cham, pp. 129-142. https://doi.org/10.1007/978-3-31967474-2_7

Hu, Y., Fernandez-Anez, N., Smith, T.E.L., Rein, G., 2018. Review of emissions from smouldering peat fires and their contribution to regional haze episodes. Int. J. Wildland Fire 27, 293-312.

Ismanto, H., Hartono, H., Marfai, M.A., 2019a. Spatiotemporal visibility characteristics impacted by forest and land fire over airports in sumatera and borneo Island, Indonesia. Quaestiones Geographicae 38, 5-16. https://doi.org/10.2478/quageo-2019-0024

Ismanto, H., Hartono, H., Marfai, M.A., 2019b. Smoke detections and visibility estimation using Himawari_8 satellite data over Sumatera and Borneo Island Indonesia. Spatial Information 
Research 27, 205-216. https://doi.org/10.1007/s41324-018-0225-8

Jolly, W.M., Freeborn, P.H., Page, W.G., Butler, B.W., 2019. Severe Fire Danger Index: A Forecastable Metric to Inform Firefighter and Community Wildfire Risk Management. Fire 2. https://doi.org/10.3390/fire2030047

Nuijens, L., Siebesma, A.P., 2019. Boundary Layer Clouds and Convection over Subtropical Oceans in our Current and in a Warmer Climate. Current Climate Change Reports 5, 80-94. https://doi.org/10.1007/s40641-019-00126-x

Nurdiati, S., Sopaheluwakan, A., Septiawan, P., 2021. Spatial and Temporal Analysis of El Niño Impact on Land and Forest Fire in Kalimantan and Sumatra. Agromet 35, 1-10. https://doi.org/10.29244/j.agromet.35.1.1-10

Nurjanah, S., Octavia, D., Kusumadewi, F., 2013. Identifikasi Lokasi Penanaman Kembali Ramin (Gonystylus bancanus Kurz) di Hutan Rawa Gambut Sumatera dan Kalimantan. FORDA PRESS.

Nuryanto, D.E., Fajariana, Y., Pradana, R.P., Anggraeni, R., Badri, I.U., Sopaheluwakan, A., 2020. Modeling of Heavy Rainfall Triggering Landslide using WRF Model. Agromet 34, 55-65. https://doi.org/10.29244/j.agromet.34.1.55-65

Pan, X., Chin, M., Ichoku, C.M., Field, R.D., 2018. Connecting Indonesian Fires and Drought With the Type of El Niño and Phase of the Indian Ocean Dipole During 1979-2016. Journal of Geophysical Research: Atmospheres 123, 79747988. https://doi.org/10.1029/2018JD028402

Patel, P., Karmakar, S., Ghosh, S., Niyogi, D., 2020. Improved simulation of very heavy rainfall events by incorporating WUDAPT urban land use/land cover in WRF. Urban Climate 32, 100616. https://doi.org/10.1016/j.uclim.2020.100616

Piani, C., Haerter, J., Coppola, E., 2010. Statistical bias correction for daily precipitation in regional climate models over Europe. Theoretical and Applied Climatology 99, 187-192. https://doi.org/10.1007/s00704-009-0134-9

R Core Team, 2021. R: A language and environment for statistical computing. $R$ Foundation for Statistical Computing, Vienna, Austria.

Sanusi, A.R., Taufik, M., Santikayasa, I.P., 2021. The Use of Weather Research and Forecasting Model to Predict Rainfall in Tropical Peatland: 1. Model Parameterization. Agromet 35, 49-59. https://doi.org/10.29244/j.agromet.35.1.49-59

Sati, A.P., Mohan, M., 2018. The impact of urbanization during half a century on surface meteorology based on WRF model simulations over National
Capital Region, India. Theoretical and Applied Climatology 134, 309-323. https://doi.org/10.1007/s00704-017-2275-6

Sharma, R., Balasubramanian, R., 2018. Sizefractionated Particulate Matter in Indoor and Outdoor Environments during the 2015 Haze in Singapore: Potential Human Health Risk Assessment. Aerosol and Air Quality Research 18, 904-917. https://doi.org/10.4209/aaqr.2017.11.0515

Skamarock, W.C., Klemp, J.B., Dudhia, J., Gill, D.O., Liu, Z., Berner, J., Wang, W., Powers, J.G., Duda, M.G., Barker, D.M., Huang, X.-Y., 2021. A Discription of the Advanced Research WRF Model Version 4.3. National Center for Atmospheric Research (NCAR), Boulder, Colorado.

Tao, Z., Chin, M., Gao, M., Kucsera, T., Kim, D., Bian, H., Kurokawa, J., Wang, Y., Liu, Z., Carmichael, G.R., Wang, Z., Akimoto, H., 2020. Evaluation of NUWRF model performance on air quality simulation under various model resolutions - an investigation within the framework of MICS-Asia Phase III. Atmospheric Chemistry and Physics 20, 2319-2339. https://doi.org/10.5194/acp-202319-2020

Taufik, M., Torfs, P.J.J.F., Uijlenhoet, R., Jones, P.D., Murdiyarso, D., Van Lanen, H.A.J., 2017. Amplification of wildfire area burnt by hydrological drought in the humid tropics. Nature Climate Change 7, 428-431. https://doi.org/10.1038/nclimate3280

Taufik, M., Widyastuti, M.T., Sulaiman, A., Murdiyarso, D. Santikayasa, I.P., Minasny, B., 2022. An improved drought-fire assessment for managing fire risks in tropical peatlands. Agricultural and Forest Meteorology 312, 108738. https://doi.org/10.1016/j.agrformet.2021.108738

Taufik, Muh., Setiawan, B.I., van Lanen, H.A.J., 2015. Modification of a fire drought index for tropical wetland ecosystems by including water table depth. Agricultural and Forest Meteorology 203, 1-10. https://doi.org/10.1016/j.agrformet.2014.12.006

Tegegne, G., Park, D.K., Kim, Y.-O., 2017. Comparison of hydrological models for the assessment of water resources in a data-scarce region, the Upper Blue Nile River Basin. Journal of Hydrology: Regional Studies 14, 49-66. https://doi.org/10.1016/j.ejrh.2017.10.002

Teklay, A., Dile, Y.T., Asfaw, D.H., Bayabil, H.K., Sisay, K., 2019. Impacts of land surface model and land use data on WRF model simulations of rainfall and temperature over Lake Tana Basin, Ethiopia. 
Heliyon 5, e02469. https://doi.org/10.1016/j.heliyon.2019.e02469

Uda, S.K., Hein, L., Atmoko, D., 2019. Assessing the health impacts of peatland fires: a case study for Central Kalimantan, Indonesia. Environmental Science and Pollution Research 26, 31315-31327. https://doi.org/10.1007/s11356-019-06264-x

World Bank, 2016. The Cost of Fire: An Economic Analysis of Indonesia's 2015 Fire Crisis., Indonesia Sustainable Landscapes Knowledge Note: 1. The World Bank.

Xu, Y., 2015. Hydrological and Forecasting $R$ package. http://dx.doi.org/10.13140/RG.2.1.4606.7040

Yáñez-Morroni, G., Gironás, J., Caneo, M., Delgado, R., Garreaud, R., 2018. Using the Weather Research and Forecasting (WRF) Model for Precipitation Forecasting in an Andean Region with Complex Topography. Atmosphere 9. https://doi.org/10.3390/atmos9080304

Yue, Y., Yan, D., Yue, Q., Ji, G., Wang, Z., 2021. Future changes in precipitation and temperature over the Yangtze River Basin in China based on CMIP6
GCMs. Atmospheric Research 264. https://doi.org/10.1016/j.atmosres.2021.105828

Yulianti, N., Kusin, K., Naito, D., Kawasaki, M., Kozan, O., Susatyo, K.E., 2020. The linkage of El Niñoinduced peat fires and its relation to current haze condition in Central Kalimantan. Journal of Wetlands Environmental Management 8, 100116. http://dx.doi.org/10.20527/jwem.v8i2.221

Zaini, J., Susanto, A.D., Samoedro, E., Bionika, V.C., Antariksa, B., 2020. Health consequences of thick forest fire smoke to healthy residents in Riau, Indonesia: a cross-sectional study. Med J Indones 29, 58-63. https://doi.org/10.13181/mji.oa.204321

Zheng, X., Klein, S.A., Ma, H.-Y., Caldwell, P., Larson, V.E., Gettelman, A., Bogenschutz, P., 2017. A cloudy planetary boundary layer oscillation arising from the coupling of turbulence with precipitation in climate simulations. Journal of Advances in Modeling Earth Systems 9, 1973-1993. https://doi.org/10.1002/2017MS000993 